Scientia Agraria Paranaensis - Sci. Agrar. Parana.

ISSN: 1983-1471 - Online

DOI: https://doi.org/10.18188/sap.v19i4.24844

\title{
HYDRO-CONDITIONING AND SEED PARTITIONING FOR Inga laurina (SW.) Willd PROPAGATION
}

\author{
Alexandre Hack Porto ${ }^{1 *}$, Américo Wagner Júnior ${ }^{1}$, Carlos Kosera Neto ${ }^{1}$, Larissa Corradi Voss ${ }^{1}$, \\ Gisely Corrêa de Moura ${ }^{1}$, Juliana Cristina Radaelli ${ }^{1}$
}

SAP 24844 Received: 06/05/2020 Accepted: 16/09/2020

Sci. Agrar. Parana., Marechal Cândido Rondon, v. 19, n. 4, oct./dec., p. 347-352, 2020

\begin{abstract}
The Inga laurina ( $\mathrm{Sw}$.) Willd species comes from tropical and subtropical regions, in several phytogeographic areas of distribution, including Brazil. It belongs to the leguminous family, present in riparian forests and used in urban afforestation, it provides shading and a pleasant microclimate, ornamental value, in addition to the fruit being consumed by man and birds. Species of this genus have compounds that are used in popular medicine. The propagation method is still by seeds, making it difficult to obtain the seedling, as they present recalcitrance, impairing its storage viability. The objective of this work was to verify the possibility of I. laurina seeds partitioning for the species propagation, and the storage viability, if previously subjected to hydro-conditioning. A completely randomized design was adopted, in a 2 x 4 factorial (Lot $\mathrm{x}$ storage time), with four replications of 50 seeds per experimental unit. The treatments were formed by the lots of whole and partitioned seeds, plus the hydro-conditioning application in the stored period. After the treatment's application, sowing was done in tubes, being kept in a 120-day evaluation period. After this period, emergence, emergence speed index, average emergence time, air length and roots $(\mathrm{cm})$, the aerial part and roots dry biomass $(\mathrm{g})$, number of roots, leaves and stems $(\mathrm{g})$ were evaluated. Seed partitioning was not proved to be advantageous. The seed partitioning technique was not proved to be advantageous. The hydro-conditioning adoption during storage allowed the seeds to remain viable and with the desired vigor.
\end{abstract}

Keywords: Inga tree, germination, storage, vigor.

\section{HIDROCONDICIONAMENTO E PARTICIONAMENTO DE SEMENTES PARA PROPAGAÇÃO DE Inga laurina (SW.) Willd}

RESUMO - A espécie Inga laurina (Sw.) Willd é oriunda de regiões tropicais e subtropicais, em diversas áreas fitogeográficas de distribuição, entre elas o Brasil. Pertence à família das leguminosas, presente em matas ripárias e utilizada na arborização urbana, fornece sombreamento e microclima agradável, valor ornamental, além do fruto ser consumido pelo homem e pássaros. Espécies deste gênero possuem compostos que são usados na medicina popular. O método de propagação ainda é por sementes o que ocasiona dificuldade na obtenção da muda por apresentarem recalcitrância, prejudicando sua viabilidade com o armazenamento. O trabalho objetivou-se verificar a possibilidade do particionamento das sementes de $I$. laurina para propagação da espécie e a viabilidade do armazenamento se submetidas previamente ao hidrocondicionamento. Adotou-se delineamento inteiramente casualizado, em fatorial 2 x 4 (lote x tempo de armazenamento), com quatro repetições de 50 sementes por unidade experimental. Os tratamentos foram formados pelos lotes de sementes inteiras e particionadas, mais a aplicação de hidrocondicionamento no período armazenado. Após a aplicação dos tratamentos, fez-se a semeadura em tubetes, mantendo-as em período avaliativo de 120 dias. Após este período avaliou-se a emergência, índice de velocidade de emergência, tempo médio de emergência, comprimento aéreo e raízes $(\mathrm{cm})$, biomassa seca da parte aérea e das raízes $(\mathrm{g})$, número de raízes, folhas e caules $(\mathrm{g})$. O particionamento das sementes não se mostrou vantajosa. A técnica do particionamento das sementes não se mostrou tão vantajosa. A adoção do hidrocondicionamento durante o armazenamento permitiu as sementes se manterem viáveis e com o vigor desejado.

Palavras-chave: ingazeiro, germinação, armazenamento, vigor.

\section{INTRODUCTION}

The Inga genus is located exclusively in tropical and subtropical regions, with seven main phytogeographic areas of distribution. In Brazil, it is located from the countryside to the coast in several biomes, expanding to the Southeast of Central America and West of South America, constituting itself as one of the main centers of diversity (PENNINGTON, 1997; MACEDO et al ., 2016). Out of 400 species total, 140 are referred to Brazil, 93 of them in the Brazilian coastal region (MATA, 2007). The Inga laurina (Sw.) Willd species has an arboreal habit, belonging to the Leguminoseae family, being present in riparian forests, also being used in urban afforestation, as it provides shading and a pleasant microclimate, ornamental value, in addition to the fruit being consumed by man and birds (BARROZO et al., 2014). In addition, species of this genus have compounds that are used in popular medicine (MARTINS et al., 2019). Propagation occurs by seeds,

${ }^{1}$ Federal Technological University of Paraná, Campus Pato Branco - Paraná, Brazil. Email: porto@alunos.utfpr.edu.br. *Corresponding author. 
with germination around 12 days after sowing. The inga tree presents polyembryonic seeds (SCHULZ et al., 2014), as it also occurs with the jaboticaba tree (Plinia cauliflora) (SILVA et al., 2019), that is, more than one seedling grows per seed. Generally, in these seeds an embryo is formed during fertilization (syngamy) and the others asexually by apomixis, which generate clone plants of the mother plant. For species that have polyembryony, seed partitioning can be advantageous for seedling production, once the species have few seeds per fruit, insufficient number of seeds or difficult to produce, since, from a single seed, more than one seedling could be obtained (WAGNER JÚNIOR et al., 2011).

Other obstacles in the inga tree seedlings production would be linked to viability after storage for a certain period, once the seed is considered recalcitrant (PRITTCHARD et al., 1995; MENDES-RODRIGUES et al., 2007), and cannot reduce its moisture content. Hydroconditioning consists of hydrating the seeds sufficiently to promote pre-metabolic activities, allowing the respiratory processes essential to germination, and, at the same time, not allowing the radicle emission. Seeds complete phases I and II of imbibition, which are requirements for germination without reaching phase III, that is characterized by cell elongation and radicle emission (SANTOS et al., 2008).

In this context, hydro-conditioning is one of the techniques that seek to extend the storage period, in addition to favoring germination uniformity, improving its percentage and speed which the process occurs, in addition to increasing seed tolerance to water and thermal stresses (BISOGNIN et al., 2016). Such techniques have not yet been tested with the inga tree seeds. In light of what has been exposed, the objective of this study was to verify the possibility of partitioning the seeds of Inga laurina (Sw.) Willd for the species propagation and the storage feasibility, if it has been previously submitted to hydroconditioning.

\section{MATERIAL AND METHODS}

Fruit harvesting was carried out in six arrays present in urban afforestation in the Dois Vizinhos (PR) municipality (geographical coordinates of $25^{\circ} 42^{\prime} 15.12$ "S and $53^{\circ} 05^{\prime} 54.20^{\prime \prime} \mathrm{O}$ ). The municipality is located in the ecoclimatic Paraná Southwest region, with an average altitude of $520 \mathrm{~m}$, predominantly red oxisol soil, climate according to the Köppen, $C f a$, subtropical classification, with hot summers, not frequent frosts and rain concentration tendency in the summer months, however, without defined dry season (ALVARES et al., 2013).

After collection, the fruits were taken to the Plant Physiology Laboratory, at the Federal Technological University of Paraná, Dois Vizinhos Campus. The fruits were in a physiological maturation stage, with a predominantly characteristic of yellow coloration of the epidermis. The fruits were washed, followed by manual removal of the seeds from the pods and aryl extraction, which involved them with light friction in a fine mesh steel sieve under running water. Then they were placed on a laboratory bench on paper towels with room temperature and humidity for $12 \mathrm{~h}$, in order to remove humidity excess.

A completely randomized experimental design was adopted in a $2 \times 4$ factorial scheme (Lot $\mathrm{x}$ hydroconditioning time), with four replications of 50 seeds per experimental unit. The seeds were separated into two lots with whole seeds (lot 1) and another in the natural divisions of the seed, that is, partitioned (lot 2). Factor 2 consisted of the levels at which the seeds were kept immersed in water for one day in plastic cups, and six days conditioned in $\mathrm{BOD}$ at $5^{\circ} \mathrm{C}$ (out of the water), remaining in this cycle for $0,30,60,90$ days.

After the application of each respective treatment, the seeds were sown in tubes of $55 \mathrm{~cm}^{3}$ filled with commercial organic substrate for plants, allocated in a greenhouse with 8 shifts of 30 minutes irrigation daily, every $3 \mathrm{~h}$. The temperature and humidity remained controlled at $25^{\circ} \mathrm{C}$ and close to $80 \%$ for the evaluation period of 120 days, respectively. After sowing, the emergency count was performed every two days, subsequently determining the emergency percentage $(\mathrm{E} \%)$, emergency speed index (IVE) (MAGUIRE, 1962) and average emergency time (TME), which culminated in the vigor and quality of seedlings (NAKAGAWA, 1999).

After seedling emergence at 120 days, aerial and root length $(\mathrm{cm})$, dry biomass $(\mathrm{g})$ and fresh aerial $(\mathrm{g})$, dry biomass $(\mathrm{g})$ and fresh $(\mathrm{g})$ roots, number of roots, leaves and stems (g) were evaluated. The data set was transformed into $\mathrm{x}+1$ root, except for emergency which was transformed by $\mathrm{x} / 100$ arc sin root to meet the assumptions of normality, with the aid of the Genes program (CRUZ, 1998). The data obtained were submitted to analysis of variance, Duncan's average comparison test $(\alpha=0.05)$ for the qualitative factor and regression analysis for the quantitative factor, by the Sanest statistical program (ZONTA et al., 1984).

\section{RESULTS AND DISCUSSION}

The results obtained with the seeds of I. laurina showed significant interaction for lot $\mathrm{x}$ hydro-conditioning time for emergence percentage (E\%), IVE, dry biomass of the aerial part, number of leaves and number of seedlings. The length of the aerial part and roots, dry root biomass and number of roots presented a significant effect in isolation by factor. The TME showed a significant effect only for the hydro-conditioning time (Table 1). Whole seeds (lot 1) demonstrated superiority to $\mathrm{E} \%$, in relation to partitioned seeds (lot 2), at 0 and 60 days of storage. At 30 days, there were no statistical differences among the averages, and at 90 days there was no emergency, regardless of whether the seeds were partitioned or not (Table 2).

Within each type of seed management, whole seeds had a greater emergence at 0 days, and partitioned seeds at 0 and 30 days (Table 2). The seeds which was kept whole at time 0 showed an emergence of $92.17 \%$, being higher than the partitioned in the same period $(49.5 \%)$. Such a condition must have provided better humidity conditions compared to partitioned ones, which when 
suffered injuries they had lost water and impaired its emergence. This fact was not repeated with those compared to 30 days, due to the beneficial effect of hydroconditioning. However, at 60 days, the superiority obtained in the whole ones is due more to the possible greater quantity of reserves to nourish it, a fact that must have limited in each partitioned piece. Such a hypothesis may justify the results obtained regarding the number of seedlings emerged in those kept in storage for 60 days. At 0 and 30 days, seedling numbers did not differ statistically between whole and partitioned ones.

TABLE 1 - Analysis of variance (ANOVA) for emergence percentage (E\%), emergence speed index (IVE), average emergence time (TME), root length (CR), dry biomass of the aerial part (BSPA), dry root biomass (BSR), number of roots (NR), number of leaves per plant (NFP), number of seedlings (NPL) and shoot length (CPA) of Inga laurina partitioned or not in storage times and hydro-conditioning.

\begin{tabular}{|c|c|c|c|c|c|c|c|c|c|c|}
\hline & & \multicolumn{3}{|c|}{$\mathrm{E} \%$} & \multicolumn{3}{|c|}{ IVE } & \multicolumn{3}{|c|}{ TME } \\
\hline $\mathrm{CV}$ & GL & SQ & QM & $\mathrm{Fc}$ & SQ & QM & $\mathrm{Fc}$ & SQ & $\mathrm{QM}$ & $\mathrm{Fc}$ \\
\hline Lot & 1 & 1262.3 & 1262.3 & $12.687^{*}$ & 0.7621 & 0.76214 & $29.747^{*}$ & 0.0007 & 0.0007 & $0.9744^{\mathrm{ns}}$ \\
\hline Time & 3 & 14828 & 4942.8 & $49.678^{*}$ & 6.582 & 2.19399 & $85.634^{*}$ & 0.01598 & 0.00533 & $7.4172^{*}$ \\
\hline $\mathrm{L} \times \mathrm{T}$ & 3 & 1231.7 & 410.6 & $4.126^{* *}$ & 0.4003 & 0.13342 & $5.208^{*}$ & 0.00251 & 0.00084 & $1.1646^{\mathrm{ns}}$ \\
\hline Residue & 24 & 2387.9 & 99.5 & & 0.6149 & 0.02562 & & 0.01723 & 0.00072 & \\
\hline Total & 31 & 19710 & & & 8.3592 & & & 0.03642 & & \\
\hline \multirow[t]{2}{*}{$\mathrm{CV}(\%)$} & & \multicolumn{3}{|c|}{33.5} & \multicolumn{3}{|c|}{11.0} & \multicolumn{3}{|c|}{2.59} \\
\hline & & \multicolumn{3}{|c|}{$\mathrm{CR}(\mathrm{cm})$} & \multicolumn{3}{|c|}{ BSPA (g) } & \multicolumn{3}{|c|}{ BSR (g) } \\
\hline Lot & 1 & 1.59 & 1.59 & $5.098^{* *}$ & 0.06845 & 0.06845 & $112.907^{*}$ & 0.0031 & 0.0031 & $17.1391^{*}$ \\
\hline Time & 3 & 37.658 & 12.5525 & $40.24^{*}$ & 0.07973 & 0.02658 & $43.8358^{*}$ & 0.00424 & 0.00141 & $7.8068^{*}$ \\
\hline $\mathrm{L} \times \mathrm{T}$ & 3 & 2.031 & 0.677 & $2.17^{\mathrm{ns}}$ & 0.02763 & 0.00921 & $15.189^{*}$ & 0.00154 & 0.00051 & $2.8399^{\mathrm{n}}$ \\
\hline Residue & 24 & 7.487 & 0.3119 & & 0.01455 & 0.00061 & & 0.00435 & 0.00018 & \\
\hline Total & 31 & 48.765 & & & 0.19035 & & & 0.01324 & & \\
\hline \multirow[t]{2}{*}{$\mathrm{CV}(\%)$} & & \multicolumn{3}{|c|}{20.07} & \multicolumn{3}{|c|}{29.4} & \multicolumn{3}{|c|}{1.32} \\
\hline & & \multicolumn{3}{|c|}{ NR } & \multicolumn{3}{|c|}{ NFP } & \multicolumn{3}{|c|}{ NPL } \\
\hline Lot & 1 & 0.2413 & 0.24125 & $15.383^{*}$ & 2.2845 & 2.2845 & $26.466^{*}$ & 0.25078 & 0.25078 & $19.122^{*}$ \\
\hline Time & 3 & 1.7071 & 0.56902 & $36.284^{*}$ & 9.605 & 3.2017 & $37.092^{*}$ & 2.02231 & 0.6741 & $51.401^{*}$ \\
\hline $\mathrm{L} \times \mathrm{T}$ & 3 & 0.1312 & 0.04374 & $2.789^{\mathrm{ns}}$ & 1.2659 & 0.422 & $4.888^{*}$ & 0.16046 & 0.05349 & $4.078^{* *}$ \\
\hline Residue & 24 & 0.3764 & 0.01568 & & 2.0716 & 0.0863 & & 0.31475 & 0.01311 & \\
\hline Total & 31 & 2.4559 & & & 15.2269 & & & 2.7483 & & \\
\hline \multirow[t]{2}{*}{$\mathrm{CV}(\%)$} & & \multicolumn{3}{|c|}{9.04} & & 15.18 & & \multicolumn{3}{|c|}{8.04} \\
\hline & & \multicolumn{3}{|c|}{$\mathrm{CPA}(\mathrm{cm})$} & & & & & & \\
\hline Lot & 1 & 1.6337 & 1.6337 & $8.488^{*}$ & & & & & & \\
\hline Time & 3 & 22.4809 & 7.4936 & $38.932^{*}$ & & & & & & \\
\hline $\mathrm{L} \times \mathrm{T}$ & 3 & 0.9435 & 0.3145 & $0.2078^{\mathrm{ns}}$ & & & & & & \\
\hline Residue & 24 & 4.6195 & 0.1925 & & & & & & & \\
\hline Total & 31 & 29.6777 & & & & & & & & \\
\hline
\end{tabular}

CV $(\%)$

$\overline{\mathrm{CV}}=$ causes of variation, $\mathrm{T}=$ time, $\mathrm{L}=\mathrm{Lot}, \mathrm{CV}=$ coefficient of variation, $*$ and $* *$ significant at $1 \%$ and $5 \%$ probability of error, respectively, ${ }^{\mathrm{ns}}=$ not significant.

The studies with seeds of Inga vera (PARISI et al., 2016) have shown results that reinforce those performed with I. laurina in the present study. Attributing the high-water content, the classification as recalcitrant that gives very high and uncontrolled metabolic activity, even after decreasing water, which results in short longevity. Given this fact, it accelerates the deterioration of the seed tissues, also associated with the development of latent fungi.

Within the partitioned seeds, the number of seedlings showed the highest averages at 0- and 30-days' time, and in whole ones up to 60 days, proving the hypothesis of the amount of reserve present in the seed and available for use. In general, such results prove the polyembryony for this species. The results corroborate with other studies such as Mendes-Rodrigues et al. (2007) by attributing the characteristic of polyembryonic seeds, in addition to being recalcitrant, as already mentioned by Schulz et al. (2014), which presents, among other characteristics, the high frequency of extra-numerical embryos, with the protrusion of up to four embryos in the same seedling.

The IVE showed a similar behavior to that obtained for E\%, when it was considered within each type of seed, being superior without storage. The index decreased as the storage period increased. Whole seeds 
must be used fresh and if partitioned, they can be stored for up to 30 days. However, in the periods of 0 and 60 days, the IVE was shown to be superior for those seeds kept whole. It is believed that partitioning reduced the number of reserves available to the embryo, thus reducing the initial vigor. This fact can be confirmed by the dry matter mass obtained, once those of whole seeds presented higher averages when compared to those partitioned in the periods of 0 and 60 days, however, without statistical difference.

TABLE 2 - Emergency speed index (IVE), percentage of emergence (E\%), dry biomass of the aerial part (BSPA), number of seedlings (NPL) and number of leaves per plant (NFP) of Inga laurina, partitioned or not at different storage and hydroconditioning times.

\begin{tabular}{|c|c|c|c|c|}
\hline Seeds lots & Whole & Partitioned & Whole & Partitioned \\
\hline Time & \multicolumn{2}{|c|}{ IVE } & \multicolumn{2}{|c|}{$\mathrm{E} \%$} \\
\hline 0 & $5.33 \mathrm{aA}^{*}$ & $2.57 \mathrm{aB}$ & $92.71 \mathrm{aA}$ & $49.50 \mathrm{aB}$ \\
\hline 30 & $1.30 \mathrm{bA}$ & $0.59 \mathrm{bB}$ & $36.09 \mathrm{bA}$ & $33.66 \mathrm{aA}$ \\
\hline 60 & $0.97 \mathrm{bA}$ & $0.11 \mathrm{bcB}$ & $29.61 \mathrm{bA}$ & $5.69 \mathrm{bB}$ \\
\hline 90 & $0.00 \mathrm{cA}$ & $0.00 \mathrm{cA}$ & $0.00 \mathrm{cA}$ & $0.00 \mathrm{bA}$ \\
\hline \multirow[t]{2}{*}{$\mathrm{CV}(\%)$} & \multicolumn{2}{|c|}{11.01} & \multicolumn{2}{|c|}{33.50} \\
\hline & \multicolumn{2}{|c|}{ BSPA (g) } & \multicolumn{2}{|c|}{ NPL } \\
\hline 0 & $0.16 \mathrm{bA}$ & $1.86 \mathrm{aA}$ & $1.86 \mathrm{aA}$ & $1.33 \mathrm{aA}$ \\
\hline 30 & $0.20 \mathrm{aA}$ & $1.85 \mathrm{aA}$ & $1.85 \mathrm{aA}$ & $1.38 \mathrm{aA}$ \\
\hline 60 & $0.16 \mathrm{bA}$ & $1.78 \mathrm{aA}$ & $1.78 \mathrm{aA}$ & $0.62 \mathrm{bB}$ \\
\hline 90 & $0.00 \mathrm{cA}$ & $0.00 \mathrm{bA}$ & $0.00 \mathrm{bA}$ & $0.00 \mathrm{cA}$ \\
\hline \multirow[t]{2}{*}{$\overline{\mathrm{CV}}(\%)$} & & & & \\
\hline & \multicolumn{4}{|c|}{ NFP } \\
\hline Lot & & & & Partitioned \\
\hline 0 & & & & $3.05 \mathrm{aB}$ \\
\hline 30 & & & & $3.42 \mathrm{aA}$ \\
\hline 60 & & & & $1.42 \mathrm{bB}$ \\
\hline 90 & & & & $0.00 \mathrm{cA}$ \\
\hline
\end{tabular}

*Averages followed by distinct lower case letters in the column, and upper case letters in the row differ by the Duncan test $(\alpha=$ $0.05)$. $\mathrm{CV}=$ coefficient of variation.

The number of leaves produced by Inga plants was higher for whole seeds, at 0 - and 60-days' time, except at 30 days when partitioned seeds showed results with no statistical difference. However, the whole seeds provided seedlings with number of leaves at a statistically similar averages from sowing at zero time to hydroconditioning for 60 days. In partitioned plants, the greatest results were when they were immediately sown or stored for 30 days. The greater number of leaves may provide a greater possibility of producing photoassimilates, consequently a better condition for seedlings to grow and/or develop initially.
When analyzing the results for the length of the aerial part and root, number of root and dry matter weight of the roots, the seed management factor was significant (Table 3). In all variables who's the lot factor was significant, the results from seeds kept whole showed the highest averages. The greater number of roots, accumulation of dry matter mass and root length are desirable characteristics for any species, since they allow better exploration of the substrate providing quality seedlings, in addition to better aggregation of the seedling substrate, which is one of the main parameters when seedlings are produced in containers (MELO et al., 2018).

TABLE 3 - Aerial part length (CPA) and root length (CR), number of roots (NR), dry root biomass (BSR) in two lots of Inga laurina seeds.

\begin{tabular}{llllr}
\hline Seeds lots & CPA $(\mathrm{cm})$ & CR $(\mathrm{cm})$ & NR & BSR $(\mathrm{g})$ \\
\hline Whole & $5.51 \mathrm{a}^{*}$ & $8.03 \mathrm{a}$ & $1.17 \mathrm{a}$ & $0.06 \mathrm{a}$ \\
Partitioned & $3.41 \mathrm{~b}$ & $5.55 \mathrm{~b}$ & $0.69 \mathrm{~b}$ & $0.02 \mathrm{~b}$ \\
\hline CV $(\%)$ & 18.87 & 20.07 & 9.04 & 1.35 \\
\hline
\end{tabular}

*Averages followed by different letters for each variable differ from each other by the Duncan test $(\alpha=0.05)$, CV = coefficient of variation, ${ }^{\mathrm{ns}}=$ not significant by the $\mathrm{F}$ test.

Larger seeds showed bigger amounts of reserves in the cotyledons, consequently, a higher percentage of emergence and initial seedling growth, such as aerial length, root and dry biomass, factors that increase the possibility of success in seedling formation (NIETSCHE et al., 2004). The storage time shown by Figure 2 was significant in isolation for the average emergence time, number of roots, dry biomass, root length and aerial part. Therefore, these variables exposed above, has shown the effect to be quadratic, whose maximum points for the 
average time of emergence, number of roots, dry matter mass of the root and length of the root, and aerial part were at 20, 15, 30, 15 and 12 days (Figures 1A, B, C, D and E, respectively). This effect showed that the hydroconditioning used in the first thirty days of storage had a positive influence on obtaining the highest averages, subsequently reducing them, a fact influenced by the higher consumption of reserves, as it has been previously highlighted.
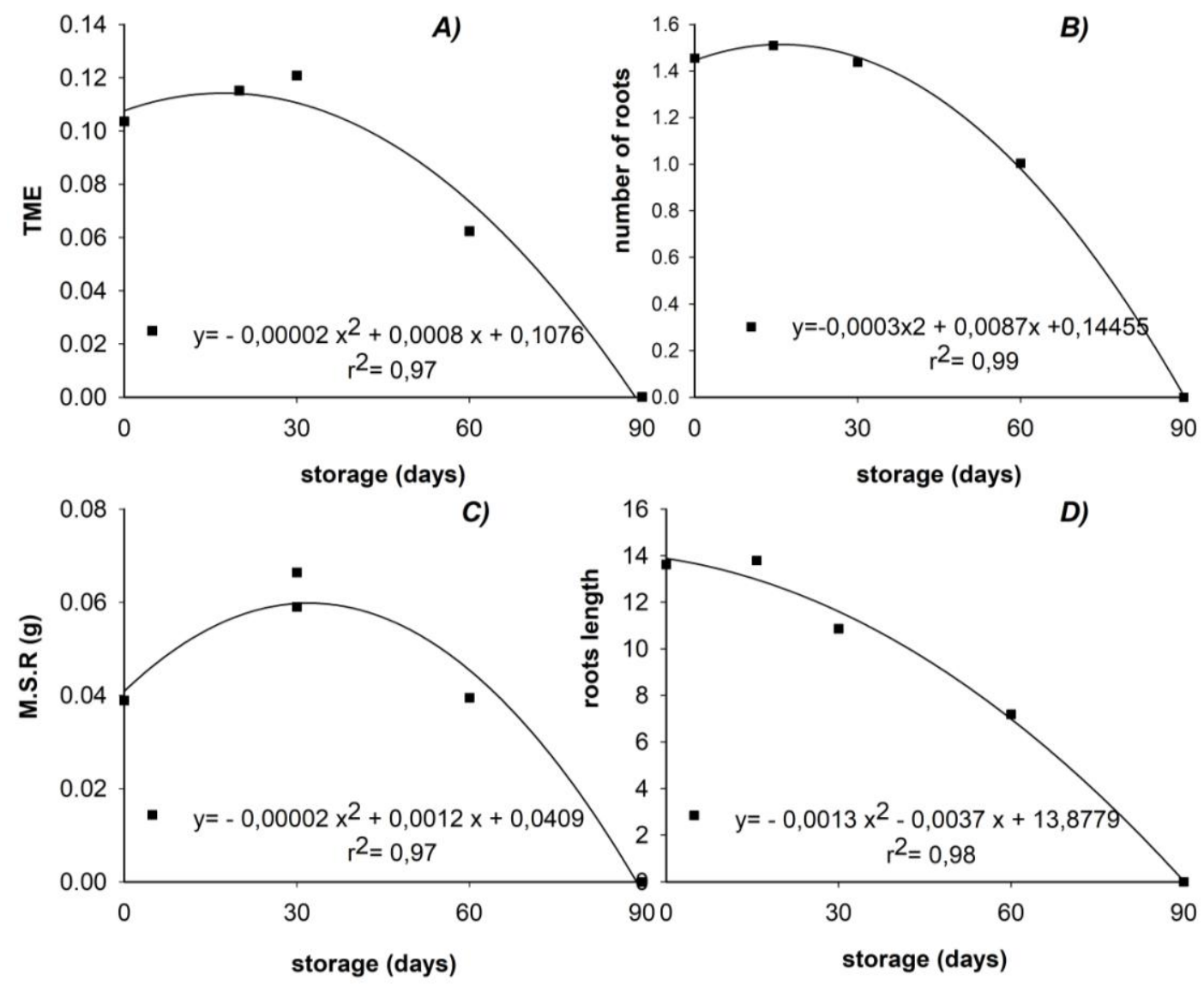

D)

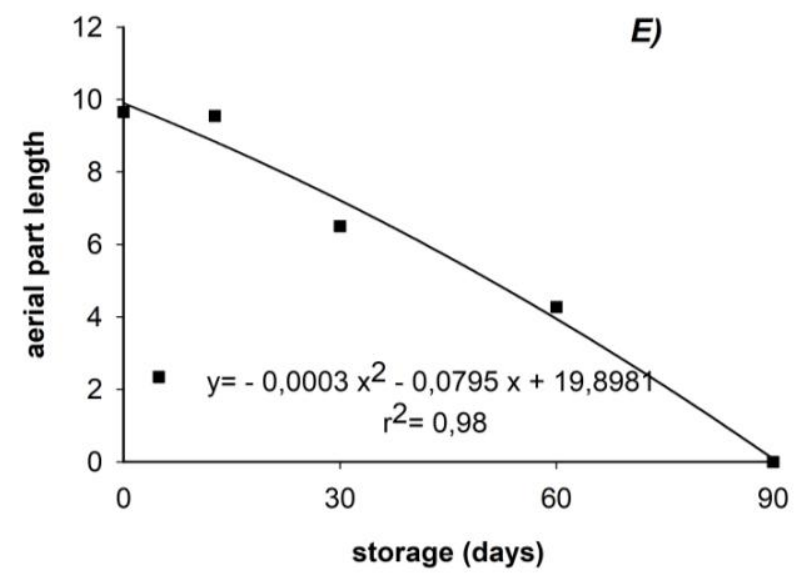

FIGURE 1 - Average emergence time (TME) (A), number of roots (B), root dry matter mass (MMSR) (g) (C), root length $(\mathrm{cm})(\mathrm{D})$ and aerial part length $(\mathrm{cm})(\mathrm{E})$ of Inga laurina, according to the previous seed storage time.

The adoption of hydro-conditioning proved to be promising in the present study. It is believed that an integrated insertion with other techniques, such as the use of packaging that modifies the atmosphere, will increase the viability time of Inga laurina seeds when stored.

\section{CONCLUSIONS}

The seed partitioning technique was not so advantageous.

The adoption of hydro-conditioning during storage allowed the seeds to remain viable and with the desired vigor. 


\section{REFERENCES}

ALVARES, C.A.; STAPE, J.L.; SENTELHAS, P.C.; MORAES, G.; LEONARDO, J.; SPAROVEK, G. Köppen's climate classification map for brazil. Meteorologische Zeitschrift, v.22, n.6, p.711-728, 2013. BARROZO, L.M.; ALVES, E.U.; SILVA, R.; NETO, A.P.A.; SANTOS, M.D.M.S.; SILVA, B.F. Substratos e temperaturas para testes de germinação e vigor de sementes de Inga laurina (sw.) willd. Bioscience Journal, v.30, n.3, p.252-261, 2014.

BISOGNIN, M.B.; KULCZYNSKI, S.M.; FERRARI, M.; GAVIRAGHI, R.; PELEGRIN, A.J.D.; SOUZA, V.Q.D. Desempenho fisiológico de sementes olerícolas em diferentes tempos de hidrocondicionamento. Revista de Ciências Agrárias, v.39, n.3, p.349-359, 2016.

CRUZ, C.D. Programa genes: aplicativo computacional em estatística aplicada à genética. Genetics and Molecular Biology, v.21, n.1, p. 135-138, 1998.

MACEDO, M.L.R.; RIBEIRO, S.F.; TAVEIRA, G.B.; GOMES, V.M.; BARROS, K.M.; MARIA-NETO, S. Antimicrobial activity of ilti, a kunitz-type trypsin inhibitor from Inga laurina (sw.) willd. Current Microbiology, v.72, n.5, p.538-544, 2016.

MAGUIRE, J.D. Speed of germination-aid in selection and evaluation for seedling emergence and vigor. 1. Crop science. Crop Science, v.2, n.2, p.176-177, 1962.

MARTINS, C.D.M.; MORAIS, S.A.; MARTINS, M.M.; CUNHA, L.; SILVA, C.V.; MARTINS, C.H.; LEANDRO, L.F.; OLIVEIRA, A.; AQUINO, F.J.; NASCIMENTO, E.A.D.; CHANG, R. Chemical composition, antifungal, and cytotoxicity activities of Inga laurina (sw.) Willd leaves. The Scientific World Journal, v.2019, Article ID 9423658, p.1-12, 2019.

MATA, F. Geographic information retrieval by topological, geographical, and conceptual matching. In: SPRINGER. International Conference on GeoSpatial Sematics, p.98-13, 2007.

MELO, L.A.D.; ABREU, A.H.M.; LELES, P.S.S.; OLIVEIRA, R.R.D.; SILVA, D.T.D. Qualidade e crescimento inicial de mudas de Mimosa caesalpiniifolia benth. produzidas em diferentes volumes de recipientes. Ciência Florestal, v.28, n.1, p.47-55, 2018.

MENDES-RODRIGUES, C.; FERREIRA, W.R.; LIMA, J.A.; DORNELLES, M.C.; RANAL, M.; SANTANA, D.G. Germinação de embriões de duas espécies de inga (mimosaceae). Revista Brasileira de Biociências, v.5, supl. 2, p.561-563, 2007.

NAKAGAWA, J. Testes de vigor baseados no desempenho das plântulas. In: KRZYZANOWSKI, F.C.; VIEIRA, R.D.; FRANÇA NETO, J.B. (Eds.). Vigor de sementes: conceitos e testes. Londrina: ABRATES, 1999. p.2-21.

NIETSCHE, S.; GONÇALVES, V.D.; PEREIRA, M.C.T.; SANTOS, F.A.; ABREU, S.C.D.; MOTA, W.F.D. Tamanho da semente e substratos na germinação e crescimento inicial de mudas de cagaiteira. Ciência e Agrotecnologia, v.28, n.6, p.1321-1325, 2004.
PARISI, J.J.D.; BIAGI, J.D.; MEDINA, P.F.; BARBEDO, C.J. Fungicide and drying effects on the viability of recalcitrant seeds of Inga vera subsp. affinis. Tropical Plant Pathology, v.41, n.3, p.177-182, 2016.

PENNINGTON, T.G. The genus Inga. Kew: Royal Botanic Gardens, 1997. 844 p.

PRITCHARD, H.; HAYE, A.; WRIGHT, W.; STEADMAN, K. A comparative study of seed viability in inga species: desiccation tolerance in relation to the physical characteristics and chemical composition of the embryo. Seed Science and Technology, v.23, n.1, p.85-100, 1995.

SANTOS, M.C.A.; AROUCHA, E.M.M.; SOUZA, M.S.; SILVA, R.F.; SOUSA, P.A. Condicionamento osmótico de sementes. Revista Caatinga, v.21, n.2, p.1-6, 2008.

SCHULZ, D.G.; ORO, P.; VOLKWEIS, C.; MALAVASI, M.D.M.; MALAVASI, U.C. Maturidade fisiológica e morfometria de sementes de Inga laurina (sw.) willd. Floresta e Ambiente, v.21, n.1, p.45-51, 2014.

SILVA, J.A.A.D.; TEIXEIRA, G.H.D.A.; MARTINS, A.B.G.; CITADIN, I.; WAGNER JÚNIOR A.; DANNER, M.A. Advances in the propagation of jabuticaba tree. Revista Brasileira de Fruticultura, v.41, n.3, e-024, 2019.

WAGNER JÚNIOR, A.; SILVA, J.O.D.C.; PIMENTEL, L.D.; SANTOS, C.E.M.D.; BRUCKNER, C.H. Germinação e desenvolvimento inicial de duas espécies de jabuticabeira em função do tamanho de sementes. Acta Scientiarum. Agronomy, v.33, n.1, p.105-109, 2011.

ZONTA, E.P.; MACHADO, A.A.; SILVEIRA JUNIOR, P. Sistema de análise estatística para microcomputadoressanest. Pelotas: UFPel, v.1, 1984. 